justly points out, blaming the failure to infect on "non-infective" particles or on "insusceptible" cells, falls into "the category of moral rather than scientific judgement". The enormous discrepancy between particle counts and infectivity titrations raises the problems of recognizing 'viruses' in the electron microscope. Pirie's chapter on the "Anatomy of Tobacco Mosaic Virus" will act as a refreshing antidote to those who infer that the size, shape and properties of the tobacco mosaic virus particle can be rigidly defined.

A diversion from the main theme on the structure, surface immunology and penetration of viruses is provided in the excellent chapter on the "Effects of Non-Ionizing radiations on Viruses" which, on the admission of the author, deals with effects on the biological activities of the virus rather than with any alteration of the component protein and nucleic acid parts.

The articles in this volume are presented in a lucid style, and they make good reading. There is, however, rather more duplication of information than one had hoped for. Virologists' addiction to 'tho glossary' is amply illustrated in this book. The origin of this practice is difficult to justify as the terms used are those of general science. If a glossary proves indispensable, then I would at least prefer a nonclassical presentation so that $I$ should know, beforehand, the meanings of the terms to be used, rather than leave it until it was too late. M. R. J. SALTON

\section{AN INTRODUCTION TO PHYSIOLOGY}

Cell Physiology

By Prof. Arthur C. Giese. Pp. xviii +534. (Philadelphia and London: W. B. Saunders Company, Ltd., 1957.) 70s. net.

W ${ }^{\text {HAT is cell physiology ? Since every organism }}$ the whole of physiology. If cell physiology is intended to cover what I would prefer to call the 'general physiology of the cell', it can be limited to those aspects of physiology which are common to all cells, such as water and salt relations, enzyme action in general, respiration, and, of course, the physical and chemical properties of protoplasm on which these processes depend. Prof. A. C. Giese, in his introductory chapter, makes it clear that what he calls cell physiology is of wider scope than this, for he says that the cellular physiologist is interested in nutrition, response to environment, growth and reproduction.

This would not seem to leave a great deal, but actually most of the book does deal with the general physiology of the cell, including the properties of protoplasm, cell division, cell membranes and the passage of water and dissolved substances through them, enzyme action and respiration. However, in line with Prof. Giese's wider conception of cell physiology, in a section devoted to nutrition, there is a chapter on photosynthesis which, although funda. mental for nearly all life, is not to be regarded as within the scope of general physiology, since it is a function limited to the chlorophyll-containing cell. Again, a whole section of five chapters is concerned with irritability and response. Thus the title of Prof. Giese's book seems to me to be a little misleading; a title such as "An Introduction to Genera]
Physiology" might, perhaps, have given a better idea of its contents. Indeed, according to the preface, this is what it is intended to be, for we are told that the book is based on a set of lectures given at Stanford University and that logical sequels to the course are "classes in plant physiology, comparative animal physiology, mammalian physiology and bacterial physiology".

As an introduction to physiology the book undoubtedly fulfils its purpose. Physical and physicochemical principles necessary for an understanding of physiological processes are dealt with adequately, and in this connexion the chapters on acidity and $p \mathrm{H}$, and on temperature and life, may be particularly noted. As regards the discussions on the various aspects of cell physiology, I can call to mind no other book designed for students beginning to study physiology which gives such an up-to-date account of these. The book is clearly written and should be of value to the students for whom it is intended.

The illustrations are clear and adequate and many are original, but why is the picture of Brownian movement on p. 10 attributed to Steel's "Physical Chemistry and Biophysics" of 1928 ? This figure appeared in the late Sir William Bayliss's "Principles of General Physiology" published in 1915, where it was attributed to Perrin, whose original paper was published in 1909 .

W. Striles

\section{TEA}

Tea

By Dr. T. Eden. (Tropical Agriculture Series.) Pp. xvi $+201+73$ Photographs. (London: Long. mans Green and Co., Ltd., 1958.) 35s. net.

$T$ is not known when tea drinking commenced but it was a custom of China even before the Christian era. The Japanese took up tea drinking from the Chinese, and Arab traders brought a knowledge of it to the West. Jesuit missionaries brought a further knowledge of it to the West in the sixteenth and seventeenth centuries. The first arrival of commercial tea in London was between 1650 and 1655 . Coffee drinking and the first English coffee houses date from about the same time. To-day the estimated consumption of tea in the United Kingdom is about $10 \mathrm{lb}$. per person per annum, while that of coffee is about $2 \mathrm{lb}$. A notable trend in recent years has been the great increase in tea drinking by some countries, especially by the local populations in many parts of the Indian subcontinent and Africa.

As up-to-date books on coffee (by Haarer) and cocoa (by Urquhart) have recently been written, it is fitting that one on tea should now appear. The author is familiar with tea production in many lands and has had a wide experience with the crop, first with the Tea Research Institute of Ceylon and later as the director of the Tea Research Institute of East Africa. All aspects of tea cultivation and preparation are doalt with by the author, and the fundamental agricultural and technological principles of the industry discussed. Much of the information presented is new or the result of recent research, particularly in such sections as those dealing with pests and diseases, manuring and vegetative propagation. The book is well written and well illustrated, and should prove of value wherever tea is grown, and as a refer. ence work. Altogether a very great deal of informa. tion has been compressed into a comparatively small space.
F. N. Howes 